\title{
THE DEVELOPMENT OF SCIENCE LEARNING MODEL BASED ON LOCAL WISDOM OF NGADA SOCIETY AT ELEMENTARY SCHOOLCOMBINED BY AUDIO VISUAL MEDIA
}

\author{
${ }^{1}$ Maria Waldetrudis Lidi, ${ }^{2}$ Yasinta Yenita Dhiki, ${ }^{3}$ Ningsih \\ ${ }^{1}$ Waldetrudismaria1024@gmail.com, ${ }^{2}$ dhikiyasinta@gmail.com, ${ }^{3}$ ningsihnd@gmail.com \\ ${ }^{1}$ Mathematics Study Program, Teacher Trainning and Education Faculty, Flores University, Ende.
}

\begin{abstract}
The objective of this research To develop the science learning model based on Ngada local wisdom at elementary school; and to describe the influences of science learning model based on local wisdom which is combined by the the audiovisual toward the students' result study. The procedures have done in this research, (1) analyzing the local wisdom potentials by using Miles and Huberman technique; (2) developing learning model combined by audiovisual media based on Dick and Carey procedures; (3) experimenting the model by using one group time series design. The varied potentials of Ngadha local wisdom namely Paruwitu, Ngo Uma, Za Ura Ngana, Adho, Sa’o Meze, Ti'i Ka Ine Ebu, Mata Uma, Kapu Ana, dan Polu Ana. Researcherschoose and develop one of the science learningmodel based local wisdom of Ngadha society, namely Paruwitu with such sintax,1) Bhe' Riwu; 2) Leba manu; 3) Paruwitu 4) Loka; 5) Mori teka lima; 6) Papa modhe. The learning materials developed categorized as good and reliable. The field implementation showed that, 1). The implementation of Paruwitu model categorized as good and reliable due to the improvement of result study; 3 ). Students give the positive responses to the learning process. Paruwitu learning model developed is proper to implement and increase the students' result study.
\end{abstract}

Keywords :Learning Model, Sains, Local Wisdom, Elementary School.

\section{Introduction}

Some education problems occurs in Ngada society is still low of education quality. Another problems are (1) the failure of education sector, especially science education; (2) the education tends to become as the "social stratification" and school sysytems only "transfer" to students; (3) Educators are not used to using technology-based learning media in learning activities; (4). Learning is not contextual; (5). Cultural values are only learned in local content subjects. Some of these problems need to get serious attention for practitioners of science education in the region through scientific research.

This was also found in primary education schools, especially in Golewa sub-district, Ngada district. The main problems include learning science in elementary schools is not contextual, cultural values are only studied in local content subjects without being integrated in other subjects, and the lack of use of technology-based learning media. The use of computers in education is limited to working on learning devices.

It is very concerning considering the characteristics of learning Science are emphasizing direct experience oriented to applicative abilities in exploring nature and overcoming various problems in life due to their interaction with nature. Therefore, in science learning the values of local wisdom should also be integrated in learning because children will learn something they experience and find in their daily lives. Applicability in exploring nature 
needs to be supported by technology. Therefore, contextual learning characterized by local community wisdom needs to be packaged in technology-based learning media, one of which is audiovisual media.

The use of audiovisual media in local wisdom-based learning models which is a form of culture is a form of education that is expected in this era because science, technology and culture have a clear relation structure. All three are a series that is inseparable in its role to meet human needs. Of the three patterns of relations, constructing concrete relations that are concrete both implicitly and explicitly covering human life[1].

Themistoklis[2], Audio-visual media play a significant role in the education process, particularly when use extensively by both teacher and children. Audio-visual media provide children with many stimuli, due to their nature (sounds, images). They enrich the learning environment, nurturing explorations, experiments and discoveries, and encourage children to develop their speech and express their thoughts. Audio-visual media is an alternative learning media based on technology. Audio-visual technology-based learning can be used as an alternative tool in optimizing the learning process, because several aspects include: a) easy to pack in the learning process, b) more interesting for learning, and c) can be fixed at any time. Through audio-visual learning media can be more interactive and more likely to occur in twoway traffic in the learning process[3].

To reach the goals, this research uses descriptive qualitative which is adopt the development model of Dick and Carey. By the development of this model, students are guided and directed to find the knowledge by the daily activities based on the social culture of Ngada.

a. Problems of research

1. What is the learning model which is appropriate to the potentials of Ngada local wisdom?

2. What are the influences of science learning model based on local wisdom which is combined by the the audiovisual toward the students' result study?

b. Aims of research

1. To develop the science learning model based on Ngada local wisdom at elementary school

2. To describe the influences of science learning model based on local wisdom which is combined by the the audiovisual toward the students' result study.

c. Limitation and scope of research

This is the Research and Development research adopted by Dick and Carey model.

This research conducted in Ngada Regency, Golewa sub district with two steps of research. First step: analyzing the potentials of Golewa local wisdom as the base of science learning model; and the second steps, experimenting the learning model for students at SDI Malanuza especialy in class IVA as the first experiment and class IVB as the second experiment by using audiovisual media.

\section{Literature Review}

There are some theories which supports this research, they are research conducted by Suastra, Tika, Kariasa[4], which examines the effectiveness of models of learning based on local culture to develop basic science competencies and the value of local wisdom in junior high school, this learning model is considered quite effective in improving basic science competencies of junior high school students. Suastra[4], focuses on developing basic competencies that contain the values of Balinese local wisdom. Our other references are Sari, Kartini and Fitriah[5], based on the results of his research concluded that the application of biology learning based on local culture science sintren arts on the concept of spermatophyta 
can improve critical thinking skills, student activities are considered more effective, and students respond positively. Sari et al, only focused on improving science skills through the application of one of the local wisdoms, namely sintren (Javanese) art. Both relevant researches used as references are based on local wisdom, the difference is in different research methods and objectives. Our research focuses on developing science learning models that adopt one of the Ngada community's wisdom in NTT Province with the aim of producing products in the form of science learning models which is appropriate with the characteristics of local communities.

\section{Material and Methodology}

This type of research is a development research using a quantitative descriptive research approach. The research design used a one group pretest-posttest design. This research was carried out in Ngada District, Golewa Subdistrict, East Nusa Tenggara Province from January to September 2018. The procedure in this study was divided into three stages: the analysis phase of the potential of local wisdom for the development of learning models with interview methods and documentation methods, the model development stage and the learning model implementation phase with the Dick and Carey development model and adapted to the 2013 curriculum. The research design used in this study was one group pretest-postest design[6] with the following patterns:

$$
\begin{aligned}
& \mathrm{R} \mathrm{O}_{1} \quad \mathrm{X} \quad \mathrm{O}_{2} \\
& \text { Description } \\
& \mathrm{R}=\text { experiment group which is taken randomly } \\
& \mathrm{O}_{1}=\text { pretest } \\
& \mathrm{O}_{2}=\text { posttest }
\end{aligned}
$$

Technique analysis such as :

1) Analzying the potentials of local wisdom by using interview, documentation, data reduction, data display, verification and conclussion.

2) Feasibility analsysis of learning materials a. Analysis validity of learning model Learning model developed then validated by expert to give an assessment. Data analysis by using qualitative descriptive to know the average of each component. The results of the average scores described as;

$1,0 \leq \mathrm{SV} \leq 1,5=$ "poor": can not be used and need many revisions

$1,6 \leq \mathrm{SV} \leq 2,5=$ "good enough": can be used with many revisions

$2,6 \leq \mathrm{SV} \leq 3,5$ ="good": can be used by little revisions

$3,6 \leq \mathrm{SV} \leq 4,0=$ "excelence": can be used without revision

Note; SV:Score of validation

Realibility measured by the Percentage of Agreement (R) formula, as cited in Borich (1994) in Ibrahim[7] :

$$
R=\left(1-\frac{A-B}{A+B}\right) \times 100 \%
$$

Notes : 
R: coefficient of Reliability

A: frequency of attitudes aspect observed which gives the high frequency

B: frequency of attitudes aspect observed which gives the low frequency

b. Analysis of process and students result study

(1). Analysis of obstacles to the learning implemenattion

It conducted by collecting, discussing, evaluating the advices given by the observer to the learning avtivities that have done

(2). Analysis of students result study Students result study analyzed by using general formula by government in curriculum 2013 .

3) Analysis of students responses

The questionaire of students response is used to know the students idea about learning process.

Students response is measured by descriptive quantitaive by using the formula of percentage of agreement, as;

$P=\frac{R}{N} \times 100 \%$

Notes :

P: the precentage of student's activities

$R$ : sum of responds

$N$ : sum of all responds

\section{Results and Discussions}

\section{The Potentials Of Ngada Society Local Wisdom}

Local wisdoms that is still entrenched in Golewa sub district, Ngada regency, East

Nusa Tenggara province, can be described as follows:

1. Paruwitu

Paruwitu is the tradition of people in Dolupore vilage in Golewa sub district, Ngada regency. Paruwitu in Bahasa means Hunting. This tradition hold on for 7 days in a group. Some groups work together to get the hunt. For hunting, hunters have to used sharp weapon, horse and sniffer dog. Paruwitu must be handled by the man, while the woman takes the little role.

2. Ngo uma

Ngo uma in Bahasa means gardening. During gardening process, people must carry out the rituals Mata Uma, as follows: (a) Sili ngawo, (b) Melihat cuaca, (c) Tuza/Zoa, (d) Kowe tanah, (e) Keti (for race)/ kua (corn, cassava, etc.)

\section{Trima}

Trima is a game played by the children, teenagers and adults when the full moon.

4. Adho/Wela Koti

Adho/Wela Koti is a game played only by the boys. Adho played after the Paruwitu rituals in groups.this game consits of two groups and the members of group muast have ana edal top.

\section{Kapu Ana}


For the pregnant woman, there are some rituals have to done before and after the bear. The ritual also continued until for the baby. Those rituals can be described as follows: (a) Gua himu., (b) Sea puse, (c) Mese azi, (d) Dhoro azi, (e) Naa puse, (f) Zezo azi, (g) Koi fu

\section{Zanga Ura Ngana}

This ritual always done by people when build the tarditional house (ka sa'o), wedding, death, surrender to the bride, etc. The animal use for the ritual is Ngana (Pig). The pig is killed and the liver is taken to be read by someone who is able to interpret its meaning based on the condition of the pig's heart, called Ngia Mali.

7. Kosubue/Ruki kosubue

This ritual aims to test the honesty of the woman who gets adolescence about chastity.

\section{The Development of Learning Model based on Local Wisdom}

1. The development of learning model Hunting tradition (Paruwitu) of Ngada society then developed as the science learning model. Model which is developed related to the learning theories as the base theory and supports the model developed. The aims, learning theories, and the result of learning development can be described as follows: 
a. The adoption of Paruwitu as Learning Model

\begin{tabular}{|c|c|c|c|c|c|}
\hline No & Paruwitu & Description & Adoption for learning & Steps & Name of Model \\
\hline 1 & $\begin{array}{l}\text { The time of } \\
\text { implementatio } \\
\mathrm{n} \text { for } 7 \text { days }\end{array}$ & $\begin{array}{l}\text { The time of implementation for } 7 \\
\text { days, means hunter is given the } \\
\text { chance and time to get the hunt } \\
\text { (animal) }\end{array}$ & $\begin{array}{l}\text { Learning model developed adopted the time } \\
\text { from Paruwitu, where in this model, students } \\
\text { are given the chance in such meeting to get } \\
\text { and construct the knowledge have. }\end{array}$ & $\begin{array}{l}\text { This model is imolemented more than } \\
\text { one meeting }\end{array}$ & \multirow{5}{*}{$\sum_{2}^{2}$} \\
\hline 1 & \begin{tabular}{l}
\multicolumn{2}{l}{ Costumary } \\
leader gather \\
people for \\
hunting (bhe \\
riwu)
\end{tabular} & $\begin{array}{l}\text { Costumary leader call some tribes } \\
\text { delegation to inform that Paruwitu } \\
\text { will begin, people have to prepare } \\
\text { their selves to Paruwitu. }\end{array}$ & $\begin{array}{l}\text { Costumary roles for learning model } \\
\text { replaced by teacher. Teacher give the } \\
\text { interesting questions related to students daily } \\
\text { lives to motivate students }\end{array}$ & $\begin{array}{l}\text { Teacher : } \\
\text { - } \quad \text { Get the students attetion } \\
\text { - } \quad \text { Inform the goals of learning }\end{array}$ & \\
\hline 2 & $\begin{array}{l}\text { Customary } \\
\text { divorce/waja }\end{array}$ & $\begin{array}{l}\text { For the man who are merrid: } \\
\text { husband and wife do customary } \\
\text { divorce. After divorce, they shall not } \\
\text { live together in the village or while } \\
\text { hunting, for example when hunting, } \\
\text { they will not gather in a group. }\end{array}$ & $\begin{array}{l}\text { Paruwitu is a group activity, and in a group } \\
\text { which consits of man and woman who are not } \\
\text { merrid. In this learning model, students are } \\
\text { divided into some groups heterogeneously. }\end{array}$ & Group division & \\
\hline 3 & Leba manu & $\begin{array}{l}\text { The men chasec the chikens around } \\
\text { the village, the chiken they got was } \\
\text { cooked and eaten with the men in the } \\
\text { house they built. (Loka). }\end{array}$ & $\begin{array}{l}\text { Chiken hunted by many people, in this model } \\
\text { replaced by the question. Teacher gives the } \\
\text { questions related to the materilas as the } \\
\text { stimulus for students to compete. }\end{array}$ & Quarrel questions & \\
\hline 4 & $\begin{array}{l}\text { Paruwitu/masu } \\
\mathrm{k} \text { ke hutan } \\
\text { untuk berburu }\end{array}$ & $\begin{array}{l}\text { 1. Group hunting go to the forest. } \\
\text { 2. In one group men are equipped } \\
\text { with sharp weapons, sniffer dogs and } \\
\text { horses, while women carry food that } \\
\text { is stored in bere (woven bags made } \\
\text { of palm leaves or pandan leaves). } \\
\text { 3. Hunting groups enter the forest in } \\
\text { different directions with the aim of } \\
\text { encircling game animals. Hunters } \\
\text { carry sniffer dogs to smell the traces } \\
\text { of the animal hunt. }\end{array}$ & $\begin{array}{l}\text { 1. The hunting group in this model is replaced } \\
\text { by a study group. } \\
\text { 2. Sharp weapons, horses and sniffer dogs in } \\
\text { the lungs, in this model are replaced by } \\
\text { student worksheets. } \\
\text { 3. Food provision, in this model is replaced } \\
\text { with the guidance of the teacher to help } \\
\text { students in each learning activity. } \\
\text { 4. Each group hunts into the forest in a } \\
\text { different direction, in this model each learning } \\
\text { group is free to determine, design and } \\
\text { implement the plan, do the task of the group. } \\
\text { 5. Hunting, in this model is replaced with the } \\
\text { activities of students working on tasks given }\end{array}$ & $\begin{array}{l}\text { - Giving group assignments and } \\
\text { guidance by the teacher from the } \\
\text { beginning to the end of the activity. } \\
\text { - Class discussion about assignments } \\
\text { done by study groups with teacher } \\
\text { guidance. } \\
\text { - Oral tests are contested by all study } \\
\text { groups. }\end{array}$ & \\
\hline
\end{tabular}




\begin{tabular}{|c|c|c|c|c|c|}
\hline No & Paruwitu & Description & Adoption for learning & Steps & Name of Model \\
\hline & & & $\begin{array}{l}\text { by the teacher with the study group assisted by } \\
\text { LKS. } \\
6 \text {. Huntedanimal in this model is the learning } \\
\text { objective that students want to achieve which } \\
\text { in this model the achievement is seen from the } \\
\text { work of the test questions. } \\
\text { Hunted animals that are both sought and } \\
\text { contested by hunters, in this model are } \\
\text { replaced by oral test questions contested by all } \\
\text { study groups. }\end{array}$ & & \\
\hline 5 & Hoga & $\begin{array}{l}\text { When getting prey, the first group to } \\
\text { kill / get hunted animals will shout } \\
\text { the name of the tribe, "hoga ...", the } \\
\text { shouting of this group and the } \\
\text { shouting of sniffer dogs is a marker } \\
\text { that game has been obtained. Another } \\
\text { group that hears will run towards the } \\
\text { sound source. }\end{array}$ & $\begin{array}{l}\text { The teacher gives several questions on the oral } \\
\text { test, each group works together in their group. } \\
\text { The group that first gets the answer with a } \\
\text { loudly voice shout the sentence of victory. } \\
\text { Another group temporarily stopped the work } \\
\text { for a moment and listened to the findings from } \\
\text { the winning group, then responded to the } \\
\text { answer. }\end{array}$ & Giving appreciation & \\
\hline 6 & Mori teka lima & $\begin{array}{l}\text { The head of the hunted animal will be } \\
\text { given to the tribe who first killed the } \\
\text { animal called Mori teka lima. After } \\
\text { the meat is brought to the village, } \\
\text { every couple who previously } \\
\text { divorced will immediately make } \\
\text { peace / reconcile at Loka. }\end{array}$ & Giving appreciation for the winning group & Giving appreciation & \\
\hline 7 & $\begin{array}{l}\text { Rujuk/papa } \\
\text { modhe }\end{array}$ & $\begin{array}{l}\text { Every couple who previously } \\
\text { divorced will eat together game that } \\
\text { has been obtained and make peace / } \\
\text { reconcile in the camp built by men } \\
\text { outside the village (Loka). } \\
\text { Peace between each pair is marked by } \\
\text { bringing, killing and eating } 1 \\
\text { chicken. }\end{array}$ & $\begin{array}{l}\text { Couple reconciliationafter the hunting activity } \\
\text { in the learning model is replaced by reflection } \\
\text { activities in the final learning activities. } \\
\text { The chickens brought and eaten by each } \\
\text { couple, in this learning model were replaced } \\
\text { by test questions to be done by each individual } \\
\text { / post test to see the achievement of the } \\
\text { expected learning objectives. }\end{array}$ & $\begin{array}{ll} & \text { Reflection } \\
\text { - } & \text { Individual test }\end{array}$ & \\
\hline
\end{tabular}




\section{b. The result of development}

The result of analysis reach the syntax of Paruwitu learning model can be desribed as the table below:

Tabel 4.2. Sintaks Model Pembelajaran Paruwitu

\begin{tabular}{|c|c|c|}
\hline No & Steps & Teacher Role \\
\hline \multirow[t]{2}{*}{1} & \multirow[t]{2}{*}{ Bhe riwu } & $\begin{array}{l}\text { The teacher displays the material as an introduction to } \\
\text { learning through audio-visual media. Then give interesting } \\
\text { questions related to students' daily lives to motivate students } \\
\text { to learn. }\end{array}$ \\
\hline & & Teacher inform the aims of the learning \\
\hline 2 & Leba manu & $\begin{array}{l}\text { Teacher gives the quarrel questions dealing with the materials } \\
\text { to know the students knowledge and in order to motivate the } \\
\text { students to learn. }\end{array}$ \\
\hline \multirow[t]{4}{*}{3} & \multirow[t]{4}{*}{ Paruwitu } & $\begin{array}{l}\text { Teacher divide students into groups and gives the assignment } \\
\text { for each groups by using students worksheet. }\end{array}$ \\
\hline & & $\begin{array}{l}\text { Students in gropus discuss about the planning and strategi to } \\
\text { do the assignment with teacher guidance }\end{array}$ \\
\hline & & $\begin{array}{l}\text { Groups do the task and teacher guidance the students to } \\
\text { construct the understanding based on the findings (based on } \\
\text { the limited time) }\end{array}$ \\
\hline & & $\begin{array}{l}\text { The things findings related to the materials keep on the Bere } \\
\text { (woven bag) and bring to the class }\end{array}$ \\
\hline 4 & Loka & $\begin{array}{l}\text { The teacher guides each group to present information based } \\
\text { on the findings and discussions in the group and other groups } \\
\text { respond. } \\
\text { The teacher provides confirmation regarding the material } \\
\text { using audio-visual media. }\end{array}$ \\
\hline \multirow[t]{2}{*}{5} & \multirow[t]{2}{*}{ Mori Teka Lima } & $\begin{array}{l}\text { Teacher give some questions, each groups work together in } \\
\text { groups. The group who firstly get the answer should shout } \\
\text { loudly. Other groups stop their work for a while and listened } \\
\text { the answer findings from the winning groups and responded } \\
\text { it. }\end{array}$ \\
\hline & & Teacher give the appreciation for the winner group. \\
\hline 6 & Papa modhe & $\begin{array}{l}\text { Teacher motivate the students to make the self reflection } \\
\text { about the materials and learning activities. }\end{array}$ \\
\hline
\end{tabular}

2. The implementation of learning materials

Learning materials developed such as Lesson Plan, Worksheet, and Assesment are validated by the experts and categorized as valid to implement in first experiment and second experiment in order to know the implementation of lesson plan and the obstacles encoutered during the learning process, students result, as the effect of the lesson plan implementation. 
The data of students result study (a). Attitude Competence

Attitude which observed are spiritual attitude and scientific attitude of students during the learning process. The high of percentage value show that students have the spiritual and scientific attitude. So, these attitudes can develop and become entrenched, teachers need to continue to practice these attitudes in their daily lives during learning process.

(b). Knowledge Competence

To measure the influence of Paruwitu learning model, reserachers give test as pretest and postest. The results of the tests are as follows;

Pict. 4.1 Diagram of Test Result of $1^{\text {st }}$ and $2^{\text {nd }}$ Experiments

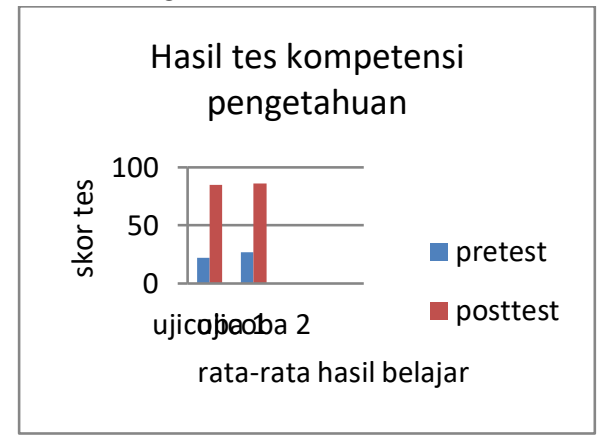

\section{(c). Skills Competence}

The assesment of skill competence consits of two products after learning the materials namely collage and clipping. The average of product ccategorized as good.

(d). Students respond

Students give the positive responds to the implementation of Paruwitu learning modelin $1^{\text {st }}$ and $2^{\text {nd }}$ experiments.

\section{Conclussions}

a. Identification result of local wisdom potential

Variety of local wisdom potential of Ngada society such as, Paruwitu, Ngo Uma, Za Ura Ngana, Adho, Sa’o Meze, Ti'i Ka Ine Ebu, Mata Uma, Kapu Ana, dan Polu Ana.

b. Validation results by experts stated that (a), the lung model was combined with audio and visual media in good and reliable categories (b) RPP was categorized as good and reliable, (c) LKS was categorized as very good and reliable, (d) category of knowledge competency tests in categories valid, understandable and reliable, good and reliable attitude observation sheets and product assessment rubrics are very good and reliable categories. e) Good and reliable category student response sheets. The results of experts validation showed that (a) Paruwitu learning model is categorized as good and reliable, (b) lesson plan is categorized as good and reliable, (c) worksheet is categorized as 
excellent and reliable, (d) test questions of knowledge competence are categorized as valid, understandable, and realiable; attitude observed sheet is categorized as good and reliable; and assesment rubric is categorized as good and reliable; (e) students respond sheet is categorized as good and reliable

c. The result of the field implementation showed that (1) the implementation of lesson plan is categorized as good, (2) the result study of knowledge comptence and skill competence reach the while students attitude competence can be developed by learning process, (3) students give the prositive respond for the learning process which is implemented by teacher.

\section{Referencess}

[1] M. Wahyudi, "Konstruksi Integralitas Ilmu, Teknologi dan Kebudayaan,” J. Pemikir. dan Pendidik. Islam, vol. 6 (2), pp. 235-249, 2016.

[2] S. Themistoklis, "Using Audiovisual Media in Nursery School Within The Framework Of The Interdisciplinary Approach,” Synerg. Sud-Est Eur., vol. 2, 2009.

[3] Haryoko, "Efektivitas Pemanfaatan Media Audio-Visual Sebagai Alternatif Optimalisasi Model Pembelajaran,” J. Edukasi, vol. 5 (1), pp. 1-10, 2009.

[4] N. K. I.W. Suastra, Tika, "Efektivitas Model Pembelajaran Sains Berbasis Budaya Lokal Untuk Mengembangkan Kompetensi Dasar Sains dan Nilai Kearifan Lokal di SMP," J. Penelit. dan Pengemb. Pendidik., vol. 5 (3), pp. 258-273, 2011.

[5] E. F. J.R. Sari, Kartini, "Penerapan Pembelajaran Biologi Berbasis Sains Budaya Lokal Kesenian Sintren Pada Konsep Spermatophyta Untuk Meningkatkan Keterampilan Berpikir Kritis Siswa SMAN 1 Ciwaringin," Sci. Educ., vol. 5 (1), pp. 1-12, 2015.

[6] Sugiyono, Metode Penelitian Pendidikan. Bandung: Alfabeta, 2010.

[7] M. Ibrahim, Pelatihan Terintegrasi Berbasis Kompetensi Guru Mata Pelajaran Biologi: Pengembangan Perangkat Pembelajaran. Jakarta: Direktorat SLTP, 2002. 